\title{
Eminent Victorian dentistry. 1. John Ruskin and the patient experience of Victorian dentistry. Ruskin's dentist, Alfred James Woodhouse
}

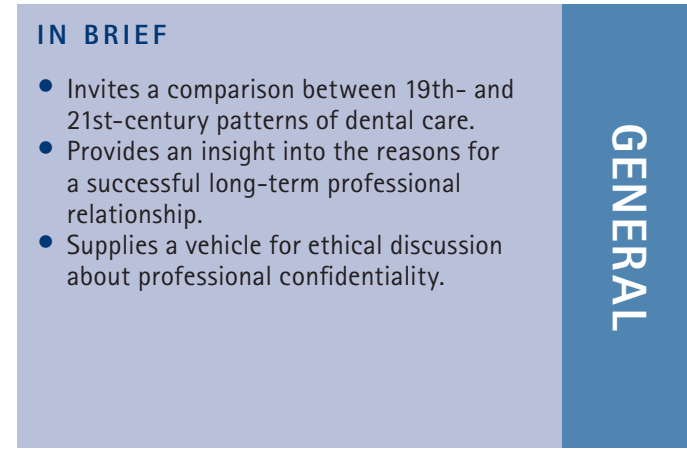

\author{
M. G. H. Bishop ${ }^{1}$
}

This paper describes the relationship between John Ruskin [1819-1900] the Victorian artist, writer, and critic, and Alfred James Woodhouse [1824-1906], the dentist who cared for him from 1866 to 1883. Although Ruskin was perhaps not quite as eccentric as a recent television series has portrayed him, he was certainly not conventional, and the relationship with his dentist was also not entirely conventional.

James Dearden's John Ruskin: a life in pictures $^{1}$ states that Ruskin (Fig. 1)'s first dentist was a Mr Rogers of 5 Sackville Street $^{2}$ (at the south end of Regent Street). Frederick William Rogers [1816-1865] obtained his licence on 2 May 1860 in the sixth batch to be issued ${ }^{3}$. He died on 26 October 1865, aged only 49, from 'disease of Spleen: ${ }^{4}$

The entry in Ruskin's diary for 18 July 1866 reveals his view of the importance of a dentist in his life, and is a reminder that to patients the retirement or death of a dentist can be a form of bereavement:

'Went into town. [...] My dentist dead. Very sorry. Went to Christie Minstrels and Royal Academy. Home very sad, and ill all evening. ${ }^{5}$

Ruskin quickly found a successor in Alfred Woodhouse (Fig. 2), five years younger than himself, who was in practice at 1 Hanover Square, ${ }^{6-8}$ and a week after finding about the death of Rogers, the diary records:

'July 25 $5^{\text {th }}$ Wednesday. Into town at 1/2 past 9 to dentist (Encouraged a little). ${ }^{5}$

Woodhouse was apprenticed in 1842 at the age of 18 to Thomas Sheffield, ${ }^{9}$ who practised in Palace Gate, Exeter from 1829

'Bulls Mill House, Hertford, SG14 3NS

Correspondence to: Mr Malcolm Bishop

\section{Refereed Paper}

Accepted 8 July 2010

DOI: $10.1038 /$ sj.bdj.2011.91

${ }^{\circledR}$ British Dental Journal 2011; 210: 179-182

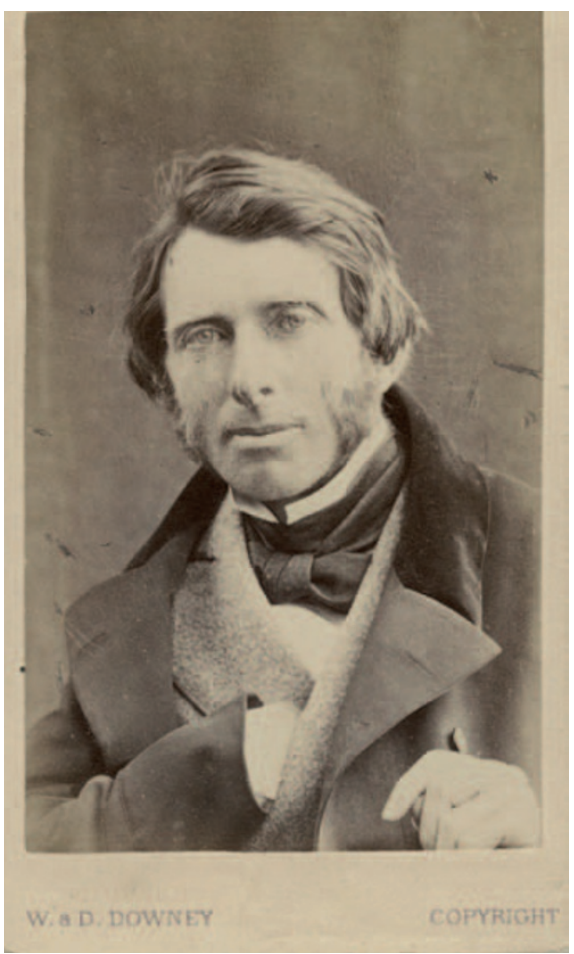

Fig. 1 John Ruskin, 29 June 1863, aged 44. William Downey for W. \& D. Downey. National Portrait Gallery, London

to $1855 .{ }^{10}$ Through Sheffield he met the Cartwrights, Nasmyth who held the royal appointment, Thomas Bell FRS, and other eminent dentists. On moving to London in 1848, he first practised from 64 Conduit Street, ${ }^{11}$ and was introduced to the young John Tomes (later Sir John, FRS) by his uncle, a surgeon. He quickly made a name for himself as one of the foremost practitioners of his day, and was the thirty-third Licentiate in Dental Surgery, receiving his licence on 20 March 1860 in the third batch to be issued. ${ }^{6}$

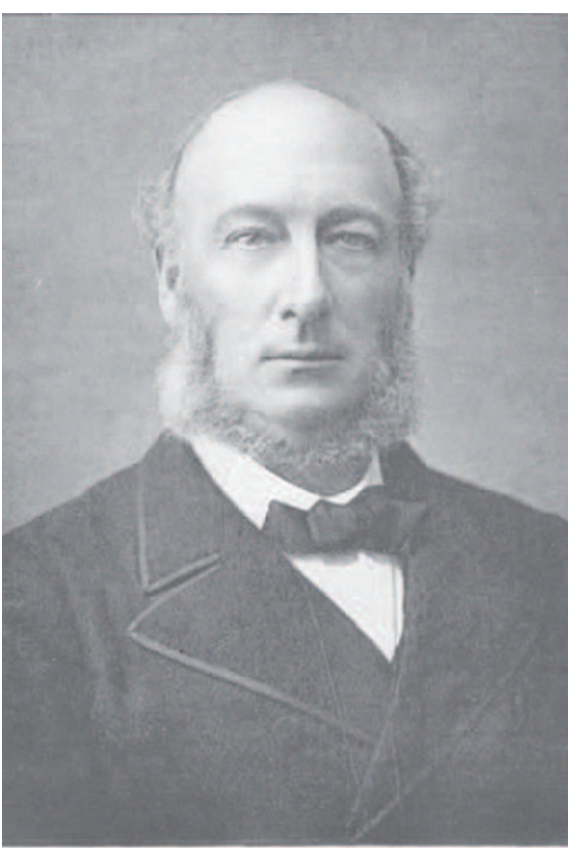

A. J. WOODHOUSE, L.D.S.Eng. Viee-President of the British Dental Associatios.
Bona I824. Died Septenober 7, 1905.

Fig. 2 Alfred James Woodhouse. By kind permission, the British Dental Association

In 1880 he became President of the Odontological Society of Great Britain, and he was a founder member of the British Dental Association, of which he became vice-president. His great work was with the Benevolent Fund, and a scholarship at the Royal Dental Hospital was endowed in his name in $1907 .{ }^{12}$

From 1858 onwards Ruskin was involved in a complex courtship of Rose La Touche, a courtship initially very much disapproved of by her parents on various grounds. (When Ruskin first 


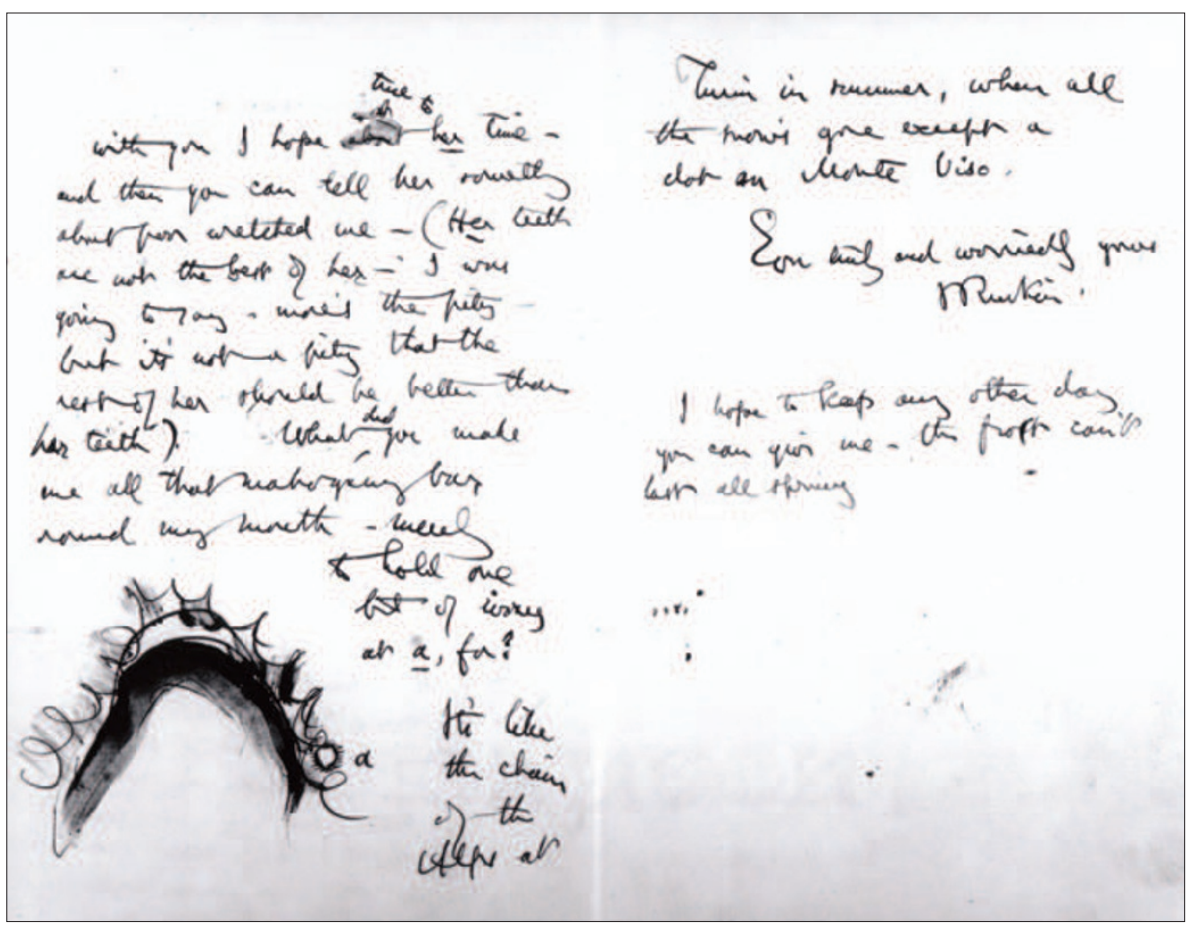

Fig. 3 Letter from Ruskin to Woodhouse, 19 January 1867 (part). The Pierpont Morgan Library, New York. Gift; DeCoursey Fales; 1962. MA 2228

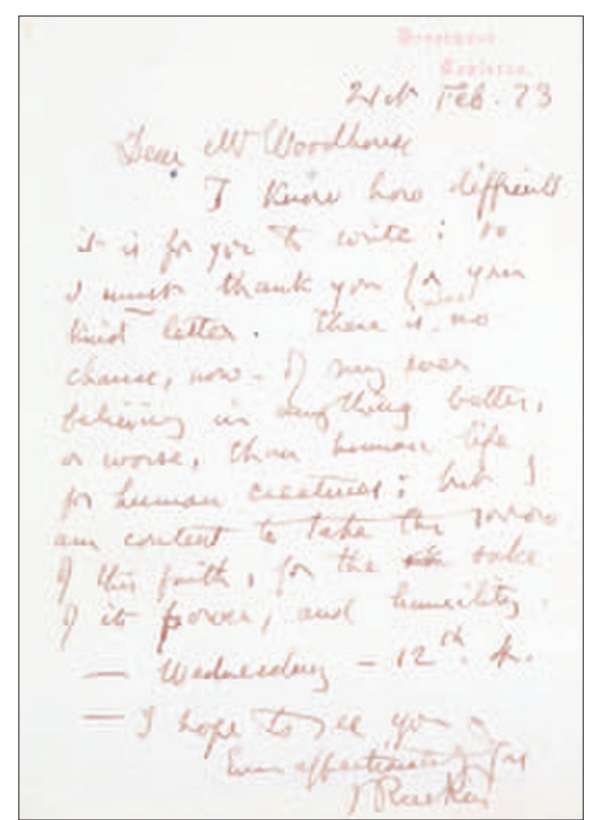

Fig. 4 Letter from Ruskin to Woodhouse, 21 February 1873. The Pierpont Morgan Library, New York. Gift; DeCoursey Fales; 1962. MA 2228. Photography: Graham Haber, 2010

Ruskin's childhood nurse stated that he was anatomically normal. ${ }^{16}$ )

Two letters from Ruskin to Woodhouse are preserved in the Ruskin archive in the Pierpont Morgan Library and Museum, New York. The first, relating to treatment for Ruskin himself and for his cousin Joan Agnew, is dated 19 January 1867, placing it in the middle of Woodhouse's initial extensive course of treatment, and was sent from Ruskin's home in Denmark Hill, close to where King's College Hospital Dental School now stands.

\section{'Denmark Hill}

19th Jan 67

\section{Dear Mr Woodhouse}

I am going to break my appointment today, for I am very comfortable just now, and am really afraid of cold or toothache if I come out in this weather: and you will have a good deal to do; for I've been practising with the teeth, and I find my long exposed upper tooth is of hardly any use, and the teeth catch and retain that more than the back ones - on which they grate with a sound of death's head and crossbones, through one's meat - and to my horror, I find that food accumulates more in front from the front teeth not being so much used - so that I never could eat before people -. My cousin will be with you I hope true to her time - and then you can tell her something about poor wretched 
me - ( Her teeth are not the best of her - I was going to say - more's the pity - but it is not a pity that the rest of her should be better than her teeth). What did you make me all that mahogany bar round my mouth - merely to hold one bit of ivory at $\underline{\alpha}$, for? [Fig. 3.]

It's like the chain of the Alps at Turin in summer, when all the snow's gone except a dot on Monte Viso.

\section{Ever truly and worriedly yours}

\section{J Ruskin.}

I hope to keep any other day you can give me - this frost can't last all spring'

At least Woodhouse had the assurance that Ruskin had tried and not just given up at the first sign of discomfort, 'for I've been practising with the teeth'. (The 'mahogany bar' almost certainly refers to a vulcanite base-plate; Woodhouse records his general use of the material. ${ }^{17}$ )

Three months later, on 24 April 1867, the diary records briefly ' $M r$ Woodhouse at dinner. ${ }^{5}$ Ruskin was conscious of the social distinctions prevalent in Victorian England, so this marks a significant development in the relationship between dentist and patient, for while Ruskin was already a major figure in English artistic circles (The Stones of Venice was published in 1851-3) Woodhouse was yet to become known for his public good works (in association with Lord Shaftesbury), scientific study and exposition, travel, history and archaeology. ${ }^{12}$ It also shows that there were no hard feelings over the 'mahogany bar' and three extractions, and that Woodhouse could face his patient at a meal! (Or indeed vice versa in view of Ruskin's comment in the letter 'I never could eat before people').

One of the extractions had been just a month earlier, an episode described in the diary, but without any particulars of where in the mouth it was:

'March $24^{\text {th }}$ Sunday. Tooth loose - awake all night, till 4. March $25^{\text {th }}$ Monday. Early in to Woodhouse. Tooth out. ${ }^{5}$

In the summer of 1871 Ruskin suffered a complete breakdown of health, mental and physical. He bought Brantwood, his house in the Lake District, and in the same year, after the death of his mother, gave up Denmark Hill, finally leaving in March 1872 and thereafter usually staying when in London at Herne Hill. In 1872 he was still suffering from depression.

Discounting the years when Ruskin was incapacitated by illness, and the initial intensive course, Ruskin visited Woodhouse at least once a year. As well as the extractions and prosthetics already mentioned, the diary for 23 December 1882 recounts gold restorations:

'Yesterday had teeth put to such rights as they can take, and had nice lesson in gold-work from Mr. Woodhouse. ${ }^{5}$ (All craftsmanship held interest for Ruskin, and Woodhouse records his gold technique in his Reminiscences. ${ }^{18}$ )

Scaling is also mentioned: 'British Hotel. London. Utterly vile fog and heavy air and I listless enough. Set to work to finish Punch lecture with prospect of teeth scraping all the forenoon.' (2 November 1883) 5

After the 1871-1872 breakdown the professional relationship was resumed, and a diary entry records a visit to Woodhouse on 8 May $1873,{ }^{19}$ breaking a journey from Oxford University (where Ruskin had been appointed as the first Slade Professor of Fine Art in 1869) to Herne Hill. The second letter from Ruskin to Woodhouse to be preserved (Fig. 4) was written three months earlier, in February, from Brantwood, and it reveals how intimate the relationship between Ruskin and Woodhouse had become. It does not relate at all to dental matters:

\section{'Brantwood \\ Coniston \\ $21^{\text {st }}$ February 73. \\ Dear Mr Woodhouse}

I know how difficult it is for you to write: so I must thank you for your kind letter. There is alas no chance, now - of my ever believing in anything better, or worse, than human life for human creatures; but I am content to take the sorrow of this faith, for the sake of its power, and humility.

$$
\begin{aligned}
& \text { - Wednesday - } 12^{\text {th }} .4 \\
& \text { - I hope to see you } \\
& \text { Ever affectionately Yrs } \\
& \text { J. Ruskin' }
\end{aligned}
$$

Dr Dearden points out ${ }^{13}$ that 2 February 1873 marked the term of the seven year period at the end of which Rose La Touche had promised to give Ruskin an answer to his proposal of marriage. Hilton provides the most likely source of the subject of the correspondence between Ruskin and Woodhouse. Ruskin knew that Rose was very ill (possibly with anorexia), and Hilton ${ }^{20}$ notes that he drew public attention to this through a letter sent on 4 November 1872 to the Pall Mall Gazette:

'I assure you, sir, insanity is a tender point with me. One of my best friends has just gone mad; and all the rest say I am mad myself. ${ }^{21}$

To the frequent embarrassment of his friends, Ruskin exposed his financial affairs and his deepest emotional life in public, and later, in January 1875 in Fors, he was to publicise the approaching death of Rose. A month before, in December 1874, he republished the Pall Mall Gazette letter in Fors at the request of a reader.

The following letter from his cousin Joan (now Mrs Severn) confirms that at this time the conversations between Woodhouse and Ruskin covered deeply personal matters. The letter also shows that Woodhouse had surprisingly little concept of patient confidentiality:

'Herne Hill. Autumn 1874. I have just returned from Mr Woodhouse where I was put to much discomfort! - he is looking forward with great joy to seeing you - he talked a little about $R$. Who goes to him again beginning of Nov. - He thinks her very clever \&t charming - \& is much interested! - Ct asked if it was to be Platonic or otherwise. I told him that was not yet certain - he fears you'll find her a worry if it's the 'otherwise!' - but I told him that you were well prepared for all that. ${ }^{22}$

In 1878, Ruskin had a further severe breakdown lasting from February to April, and not long afterwards his senior medical advisor, John Simon FRS, was concerned that Ruskin was using the excuse of his visits to Woodhouse in another way, writing on $4^{\text {th }}$ August 1879 to say:

'I hear, however, to my regret that he is now at work in London (whither he had come with Dentistic requirements). ${ }^{23}$

As Hilton notes in his biography, Simon 'prevailed on the Severns and other interested parties to take Ruskin away from his Turner studies and his too numerous London engagements. ${ }^{24}$ The need for Woodhouse was genuine enough, as two entries made at Brantwood in February 
and March 1879 reveal:

'Threatening toothache at intervals to cheer me, and make me thankful when it goes away again. So begins the last day of my 59 ${ }^{\text {th }}$ year.' And; 'tooth which was threatening, relieved. ${ }^{25}$

Although there are several other entries relating to teeth and toothache in the diary, the last diary reference to Woodhouse (or any dentist), 'Finished with teeth yesterday', appears on 24th November 1883, when Ruskin was 64 years old.

A final attack of mania in August 1889 brought all creative work to an end and Ruskin died of 'Influenza and Syncope' eleven years later at Brantwood on $20^{\text {th }}$ January 1900, aged $80 .{ }^{26}$

\section{Dental postscript 1}

As the great champion of the work of J. M. W. Turner, Ruskin served the historical record of the profession well by preserving and cataloguing the sketchbook drawings of a Regency dentist's rooms which were described in two papers in this journal. ${ }^{27}$

\section{Dental postscript 2}

By 1883 Mrs La Touche, no longer estranged from Ruskin, was seeing a ' $\mathrm{Mr}$ Bullen', [probably Frederick Bullin (sic) of White Friars House, Chester, who qualified LDS RCS on 19 February 1861]. Writing to Ruskin's cousin from the Queen Hotel, Chester, she says:

'Dearest Joanie, We are getting so impatient - I'm tired of sitting all day in $\mathrm{Mr}$ Bullen's chair with my mouth full of fingers. But this is to be final, \& I must give him the time now which I ought to have given him in April. ${ }^{28}$

\section{Dental postscript 3}

Sir John Simon FRS, (1816-1904) Privy Councillor, President of the Royal College of Surgeons, President of the Royal Society, and Ruskin's friend and senior medical advisor, was at one time Chief Medical Officer to the General Board of Health and as such of enormous importance to the advancement of dentistry as a profession, when in 1856 he drafted Cowper's Bill, which, with the inclusion of (Sir) John Tomes' amendment, permitted the institution of the LDS examination by the Royal College of Surgeons. ${ }^{29}$

\section{Dental postscript 4}

There are many references in the diaries to Ruskin's great friend Sir Henry Wentworth Dyke Acland Bt. (1815-1900). Sir Henry had been President of the General Medical Council, and held the post of Regius Professor of Medicine at Oxford University. ${ }^{30}$ His nephew the Rt. Hon. Sir Francis Dyke Acland Bt MP. (1874-1939) continued the family's involvement in the governance of the medical profession when he was appointed as the first Chairman of the Dental Board on 22 November 1921, when, following the Dentists Act, dentistry at last became a closed profession.

Thanks to Professor Michael Wheeler for first drawing my attention to the Woodhouse letters, and to him, Professor Stephen Wildman of Lancaster University, Dr Malcolm Hardman of Warwick University, and Dr Dearden for information and advice on the preparation of the paper. Thanks are also due to Helen Nield at the BDA Information Centre and Kay Walters, Librarian of the Athenaeum.

I thank the British Dental Association, the Pierpont Morgan Library, New York, The National Portrait Gallery London, the Ruskin Foundation, the Ruskin Library and Research Centre Lancaster University, and Yale University Press for permissions.

1. Dearden J S. John Ruskin: a life in pictures. Sheffield:
Sheffield Academic Press, 1999.

2. Post Office Directory.

3. Cohen E M. The earliest licentiates in dental surgery. Dental Historian 2000; 37: 35. 4. GRO Certificate of Death. Marylebone. Vol 1 a p.389.

5. Evans J, Whitehouse J H eds. The Diaries of John Ruskin. 3 Vols. Oxford: Clarendon Press, 1956-1959.

6. Cohen E M. The earliest licentiates in dental surgery. Dental Historian 2000; 37: 34.

7. Envelope for 1873 letter from Ruskin; see Fig. 4.

8. Dentists Register.

9. Woodhouse A J. Reminiscences of fifty-four years in the dental profession. J Br Dent Assoc 1897; 18: 23.

10. Hillam C. Brass plate and brazen impudence. Liverpool: Liverpool University Press, 1991. pp 230-231.

11. Post Office Directory.

12. Obituary. Br Dent J 1906: 27: 907-908.

13. Dearden JS. Personal communication.

14. Hill A. The history of the reform movement in the dental profession in Great Britain during the last twenty years. London: Trübner \& Co., 1877. p 308.

15. Hilton T. John Ruskin: the later years. New Haven: Yale University Press, 2000. p 299.

16. Severn J. Letter to Mrs Alexander. In Viljoen. H G. ed. The Brantwood Diary of John Ruskin Yale: Yale University Press, 1971. p 369.

17. Woodhouse A J. Reminiscences of fifty-four years in the dental profession. J Br Dent Assoc 1897; 18: 28.

18. Woodhouse A J. Reminiscences of fifty-four years in the dental profession. J Br Dent Assoc 1897: 18: 25.

19. Viljoen $\mathrm{H} \mathrm{G}$ (ed). The Brantwood diary of John Ruskin. New Haven: Yale University Press, 1971. p 351.

20. Hilton T. John Ruskin: the later years. New Haven: Yale University Press, 2000. pp 249-250.

21. Ruskin J. Pall Mall Gazette 4 Nov. 1872, Reprinted by Ruskin: Fors Clavigera Dec 1874.

22. Bembridge M S I. 62. In Hilton T. John Ruskin; the later years. New Haven: Yale University Press, 2000 p.299.

23. Simon J. Letter to Charles Eliot Norton. In Viljoen H G (ed) The Brantwood diary of John Ruskin. New Haven: Yale University Press, 1971. p 136.

24. Hilton T. John Ruskin: the later years. New Haven: Yale University Press, 2000. p 394.

25. Viljoen H G (ed). The Brantwood diary of John Ruskin. New Haven: Yale University Press, 1971. pp 154-162.

26. GRO Certificate of Death. Ulverston. Vol. 8e p 753

27. Bishop M G H, Gelbier S, King J. J. M. W. Turner's painting "The unpaid bill, or the dentist reproving his son's prodigality". Br Dent J 2004; 197: 757-762 and Bishop M G H, Gelbier S, King J. Science and technology in Turner's Georgian dentist's rooms. $\mathrm{Br}$ Dent J 2005: 198: 299-303.

28. La Touche M. Letter to Mrs Severn. 14 July 1883. In Viljoen H G (ed) The Brantwood diary of John Ruskin. New Haven: Yale University Press, 1971. p 471.

29. Bishop M G H. Parker M. 'Sir John Tomes FRS, Fellows of the Royal Society, and dental reform in the nineteenth Century'. Notes Rec. R. Soc. 2010; 64: 408

30. Obituary. Br Med J 1900; 3 November. p 1349. 